\title{
RECONSTRUCTION AND RESTORATION OF HISTORICAL MONUMENTS: INTERNATIONAL EXPERIENCE
}

\author{
Olga Pastukh ${ }^{1 *}$, Timothy Gray ${ }^{2}$, Svetlana Golovina ${ }^{1}$ \\ ${ }^{1}$ Saint Petersburg State University of Architecture and Civil Engineering \\ Vtoraja Krasnoarmeyskaya st., 4, Saint Petersburg, Russia \\ ${ }^{2}$ Ball State University \\ Muncie, USA, Indiana
}

* Corresponding author: gvolia@yandex.ru

\begin{abstract}
Introduction: In addition to recognizing and taking into account the vital need for the maintenance and repair of historical structures, this study will focus on their inherent design potential at the intersection of the new and the old. Purpose of the study: The study aims to review the approach to restoring such landmarks as the library in Vyborg and the Arsenal building in the Nizhny Novgorod Kremlin. We will also focus on the restoration of more mundane structures. In addition to historical monuments, this study will look at instances when there is no attempt to return the buildings to some idealized version of the past, but instead, the restoration process is used to celebrate the qualities of the buildings' age in the here and now, and to recognize that they are living, evolving, and constantly changing entities. Methods: The study uses the method of analysis, which we apply to the standard solutions for various purposes and objects, in the form of structural and technological protection of cultural heritage sites during their restoration and adaptation. The use of modern restoration materials and protective structures' construction technologies will help protect the environment while taking into account LEED, BREEAM, the Energy Star program (the USA), and the GREEN ZOOM standards. Results: We offer selected examples from contemporary practice in Europe, the United States, and Russia to illustrate these approaches to restoration, including two student-led architectural installations that explore the creative intersection between the new and the old. Discussion: Discussing the execution of specific restoration and reconstruction projects reveals the importance of international cooperation in the development of educational strategies and practices in the field of conserving and restoring the cultural heritage. The growing volume of conservation and restoration work is putting pressure on the development of research approaches and methodologies aimed at solving practical problems. At the same time, the restorer must be mindful of continuity with the past when reconstructing the more mundane and utilitarian structures that can benefit from less restrictive approaches to the intersection of the old and the new.
\end{abstract}

\section{Keywords}

Architectural heritage, restoration, adaptation, innovation, historical building structures, European experience, Russian experience, American experience, architectural installations.

\section{Introduction}

The preservation of architectural monuments periodically involves conservation and restoration, which is provided with a theoretical rationale. The conservation and restoration methods used are fluid and require each restorer to take a creative approach to solving the project-specific issues. Conservation of a cultural heritage site is defined as research, survey, and design and production work, including the complex of emergency activities aimed at protecting a cultural heritage site that faces rapid destruction, as well as preventing the site's deterioration (Jurow, 1978). In Russia, monument restoration is currently classified under the protection of cultural heritage sites, according to Article 41 of Federal Law No. 73-FZ of the Russian Federation of June 25, 2002.

The activities specified in conservation projects are carried out in order to prevent the building's further destruction under the influence of atmospheric precipitation. That is why the issue of conducting this type of work under the protection of outdoor canopies over cultural heritage sites is particularly relevant. The existing structural and technological solutions for the construction of outdoor canopies over cultural heritage sites during restoration and adaptation can be supplemented and improved with the use of new technical solutions for geodesic domes made out of timber and high-strength polymers (Handel, 2013). This will not only significantly reduce the strain in the load-bearing structures, as compared to metal and reinforced concrete, but also provide an opportunity to take care of the environment in accordance with European LEED, BREEAM, the Energy Star program (the USA), and the Russian GREEN ZOOM standards (Tuan, 1974).

The methods of conservation and restoration used in this case require each restorer to take a creative approach to resolving the issues specific to a given project (Lowenthal, 1985). 
When determining the appropriate technique for restoring a public landmark, it is crucial to assess its historical and architectural value. Structures that have less historical significance can offer the designer a greater license to creatively employ a broader range of modern building materials. A decision on reconstruction can only be made when the structure's architectural value is low or when the historical structure is in a neglected state of disrepair, requiring immediate intervention to preserve and extend its service life. Reconstruction is also possible when it is necessary to replace the site's utility system in accordance with the modern requirements of a constantly developing city.

To determine the technical condition of a building, it is necessary to have information about its actual structural strength, stiffness, the presence and location of its rigid joints, uniformity, material density, etc. (Lysova and Shalygina, 1979).

The Russian experience of restoration with modern construction materials and technologies can be exemplified by some of the outstanding monuments in St. Petersburg, many of which are under UNESCO protection.

\section{Methods}

Chapter 7 of Federal Law «On Objects of Cultural Heritage of the Peoples of the Russian Federation» prescribes a number of concepts that define the possible measures to be taken in order to preserve a cultural heritage site: conservation (Article 41), repair (Article 42), restoration (Article 43), adaptation of the site for modern use (Article 44 ), etc. (Federal Law No. 73-FZ of June 25, 2002). Restoration and adaptation are currently considered the most relevant. The concept of «reconstruction» is not included in the Federal Law, but the TownPlanning Code of the Russian Federation (clause 14) allows for certain measures in a situation where there are few protected landmarks on the site (Town-Planning Code of the Russian Federation No. 190-FZ of December 12, 2004). Besides, subclauses 14.1-14.3 provide the additional necessary clarifications for the definitions.

The authors of this study suggest using the geodesic dome design for preserving cultural heritage sites, both during restoration and adaptation and during the conversion into a museum.

This issue has already been raised by undergraduates of the Saint Petersburg State University of Architecture and Civil Engineering. In particular, in his final master's thesis in 2018, Ayat Alnajar proposed solutions for the construction of enclosures over historical buildings and structures, using the preservation of cultural heritage in Jordan as an example.

This technical solution has a number of advantages when applied to archaeological work and the restoration of cultural heritage sites:

1. There is no precipitation in the work area.
2. The microclimate remains favorable for both the cultural heritage site and the restorers throughout the restoration process.

3. The team can move freely while carrying out technological operations in the work area.

4. Work can be done at any time of the year 24/7.

5 . The risk of work deadline disruption is reduced.

6 . The restoration quality improves.

Researchers and experts around the world continue studying renewable energy from natural sources. Using the geodesic dome surface is an excellent solution to this issue (Pastukh and Zhivotov, 2020).

The use of modern building materials in the restoration of historical landmarks will not only significantly upgrade and strengthen the supporting structures but also provide an opportunity to take care of the environment, taking into account European LEED and BREEAM, the Energy Star program in the USA, as well as the Russian GREEN ZOOM standards.

Over the recent years, we have been seeing the active introduction of innovative technologies. New methods of restoration and adaptation of cultural heritage sites are being applied in various Russian cities in order to meet the needs of modern society. We would like to refer to specific historical landmarks in Nizhny Novgorod and Vyborg to illustrate this approach.

We will also consider examples from foreign experience, modest in scale but still important, in that they provide a frame of reference for evaluating the preservation strategy. These examples include the work on the creative solution that was used to breathe life into the ruins of a Gothic church that had been badly damaged in World War II and remained so until its restoration in the 1990s, in Müncheberg, Germany. During the Küppersmühle renovation in Duisburg, Germany, Herzog and de Meuron were asked to convert an iconic industrial facility into a museum to house postwar German art.

We will also offer two student-led projects that use an investigation of the ordinary as a catalyst for design, resulting in new architectural installations that both emerge from the existing environment and amplify and reveal its aspects.

\section{Results}

\section{Architectural Heritage Sites in Russia}

1.1. Building of the City Library Named After N. K. Krupskaya, Architect Alvar Aalto (1933-1935), Vyborg

The Library is considered a cultural heritage site of federal significance in modern Russia. The renovation of the Library in Vyborg was an important process and an interesting example of restoring and preserving modern architecture. The aim of the restoration was to restore the building's architectural value, as well as to meet the modern needs for functionality and security. The necessary 
funds were allocated from the Russian budget for the restoration of the building in 2010, with the assistance of the federal authorities, former President of Finland Tarja Halonen, and Russian President Vladimir Putin. The «rescue» of the Library in Vyborg was carried out jointly by Russian and Finnish experts and supported by the International Council on Monuments and Sites (ICOMOS) and the city administration of Vyborg. The great value of the Library building is recognized by the authorities in Moscow and St. Petersburg.

The new Library opened on October 13, 1935, was designed by young but already famous architect Alvar Aalto. He used three solutions that are now regarded as central to his approach. The first solution is a revolutionary lighting system in the reading hall, with fifty-seven individual apertures in the ceiling. They supply a steady diffused light that is reflected off the walls, which have a matte finish and are whitewashed with lime. The second solution is the noteworthy design of the reading hall, with a desk for librarians that is as solemn as a church pulpit. The third solution is a lecture hall with a wave-shaped ceiling made out of light wood, which is a very appealing feature (Figure 1).

The restoration accounted for the prospect of Aalto's Library being potentially added to the UNESCO World Heritage List. This meant preserving all the existing original elements at the
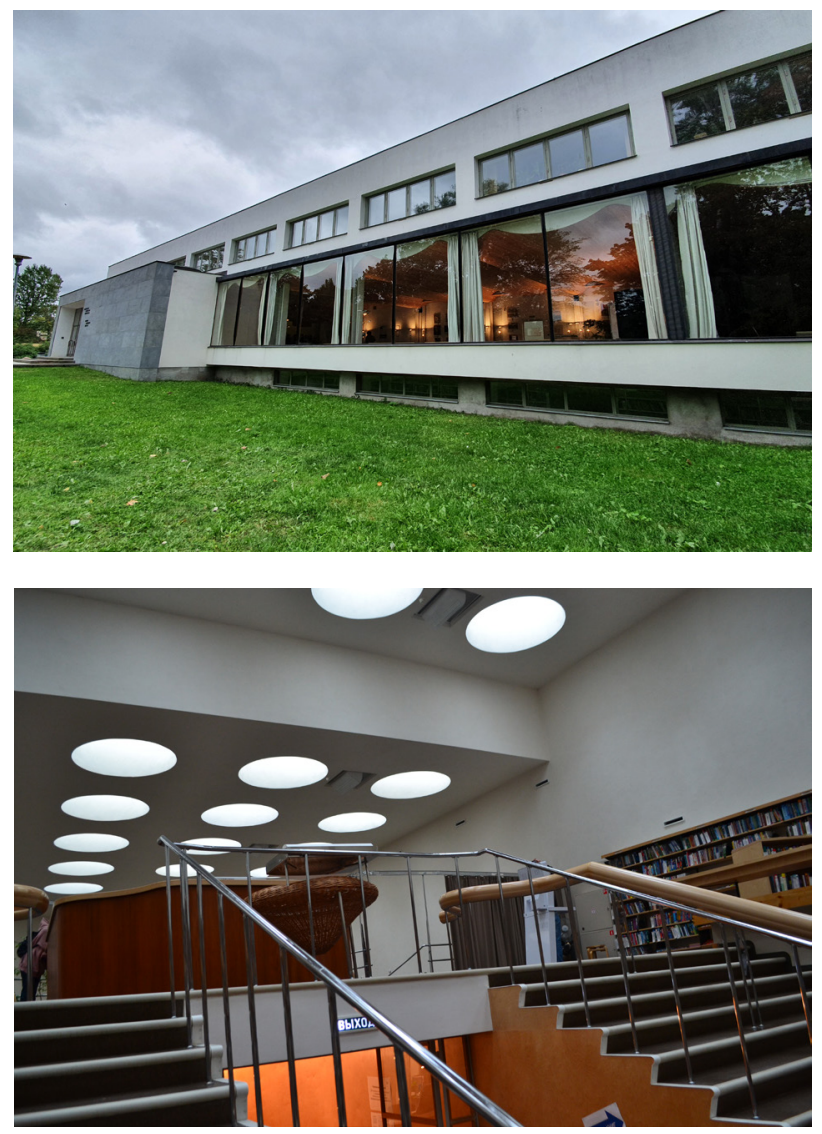

beginning of the restoration and reproducing the lost elements as accurately as possible. At the same time, the building still had to remain functional as a library, so it needed to meet the modern requirements for library technologies, security, energy conservation, etc. The task was significantly facilitated by the availability of a complete set of initial design documentation and a number of models of individual elements. A detailed photo survey, taken immediately after the construction was completed, was also an important tool for restoring the original appearance of the Library. The on-site survey, started in 1987 by Vyborg architect Sergey Kravchenko, was continued by experts from the St. Petersburg Scientific Research Institute "Spetsrestavratsiya». After the completion of the most urgent work in 1994, successive sub-projects were launched to restore the building's individual parts and elements. The Finnish Committee's supervision over the work process and staff training ensured a high quality of work (Figure 2).

The restoration of the Library in Vyborg, designed by legendary Finnish architect Alvar Aalto, lasted for almost 19 years and received the highest award of a prestigious organization - Europa Nostra Award 2015. The preservation of the Library was celebrated during a joint ceremony, the European Union's Cultural Heritage and Arts Awards / Europa Nostra Awards, at the Oslo City Hall in Norway.
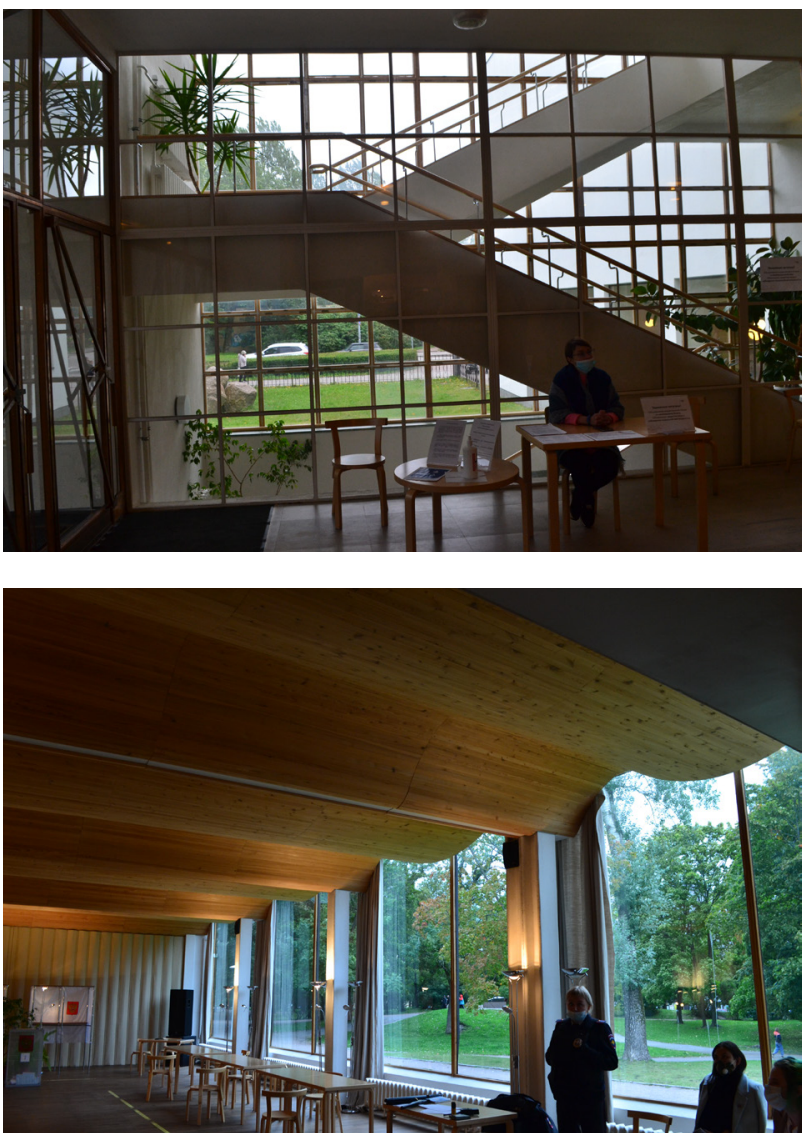


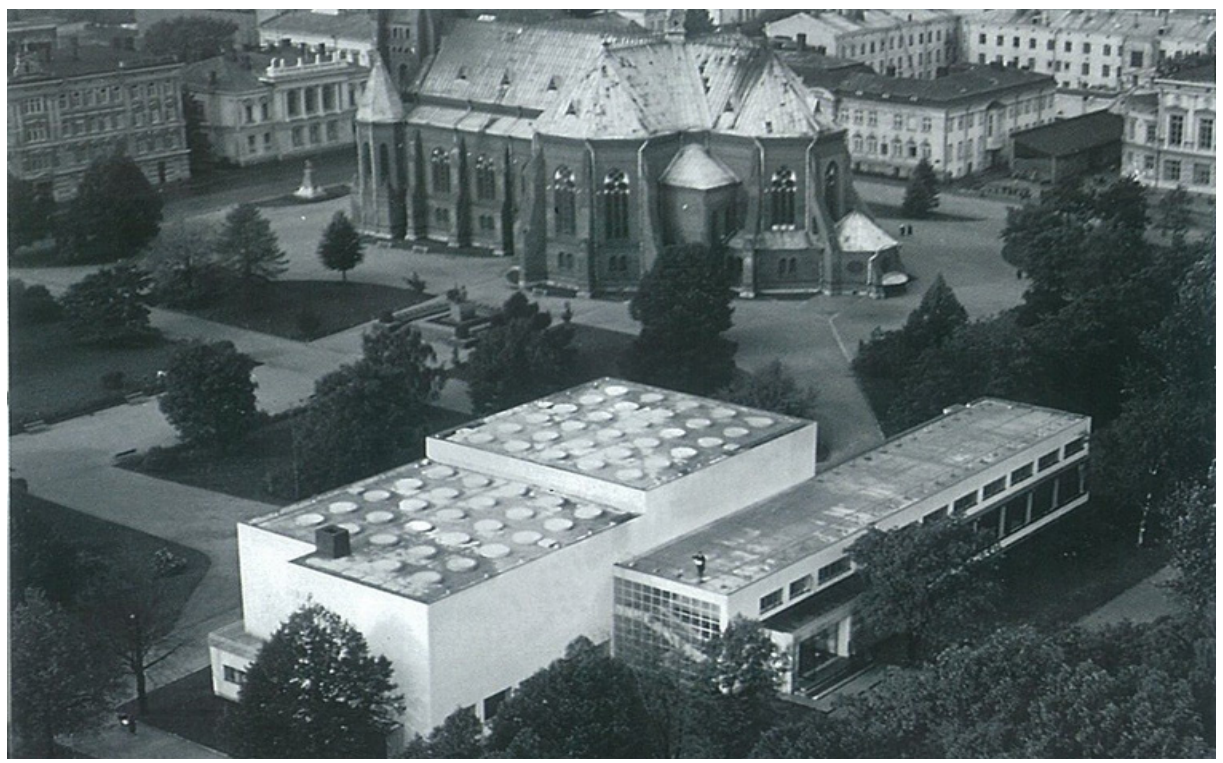

Figure 2. Alvar Aalto Library building, 1933-1935, the city ensemble

\subsection{Arsenal building on the territory of the Kremlin, Nizhny Novgorod}

The Arsenal building (1840-1843), built in the classical style, is located in the heart of Nizhny Novgorod, in the Kremlin. The Kremlin's territory is mostly occupied by the municipal and regional authorities, and culture is represented only by official academic institutions, such as the Philharmonic Society and the Art Museum. The architectural aspect of the Arsenal building has always been secondary in importance. The functional aspect of the Arsenal is secondary as well: while built for storing weapons and ammunition, it was never used in this capacity, as the military significance of the fortress had already been lost by the middle of the $19^{\text {th }}$ century. After the revolution of 1917 , the building was used as an archive by the Cartographic Service of the Ministry of Defense for many years, until being transferred to a branch of the NCCA (National Center of Contemporary Art) in 2003. The ambitious idea to create a branch of the NCCA in this building belongs to architect Evgeny Ass, as well as to A. Gor and L. Saprykina, heading the Center's Nizhny Novgorod branch (Farahat and Osman, 2018). The appearance of the Arsenal has not changed. The facades of the building have been carefully restored. The roof is painted with verdigris, as was the custom in the $19^{\text {th }}$ century (Figure 3 ).

The quality of the spaces created in the Arsenal after the reconstruction can be considered almost perfect. The vaults and walls of the Arsenal building date back to the $19^{\text {th }}$ century, but the interiors are notably modern. Architect Evgeny Ass has recognized, identified, and emphasized the monument's advantages and turned the utilitarian building into a fully-fledged public space. The architecture quite accurately reflects the strategy that the NCCA Nizhny Novgorod branch adheres to when promoting contemporary art in the Volga region (Pastukh, 2016). The space's architectural solution is based on a clear articulation of the old and the new. The red brick walls and vaults, as well as the Kremlin wall that is integrated into the building, have been carefully restored and have had plaster cleaned off them. The cast-iron flooring on the ground floor has been well preserved. The uneven man-made surfaces of the historical structures contrast with the obvious technological efficiency of the modern elements that have been introduced into the interior. The authentic features have not been replaced by replicas; rather, new designs catch the eye without trying to mimic the high antiquity (Kharlamov, 2011). The color scheme is laconic: red brick, black castiron flooring on the ground floor, and grayish-white modern additions (Figure 4).

\section{Renovation of American Historical Sites.}

\section{Student-Led Projects}

\subsection{RedBARN Installation}

In addition to the above, one of the authors has contributed to student projects that examine similar situations. These projects strip away any functional agenda and allow for a creative approach, which is informed by an examination of the current environment. The redBARN installation project began with a detailed analysis of an existing historical barn located in central Indiana, USA. The insights from this analysis informed a site-conditioned response, where the architectural response «draws all of its cues (reasons for being) from its surroundings» (Irwin, 1985).

In this project, the student team was asked to spend some time exploring the historical barn at a leisurely pace. The students were from the central Midwestern region of the USA, so they were familiar with this type of building. They were then asked to write about their experience in the barn and their 


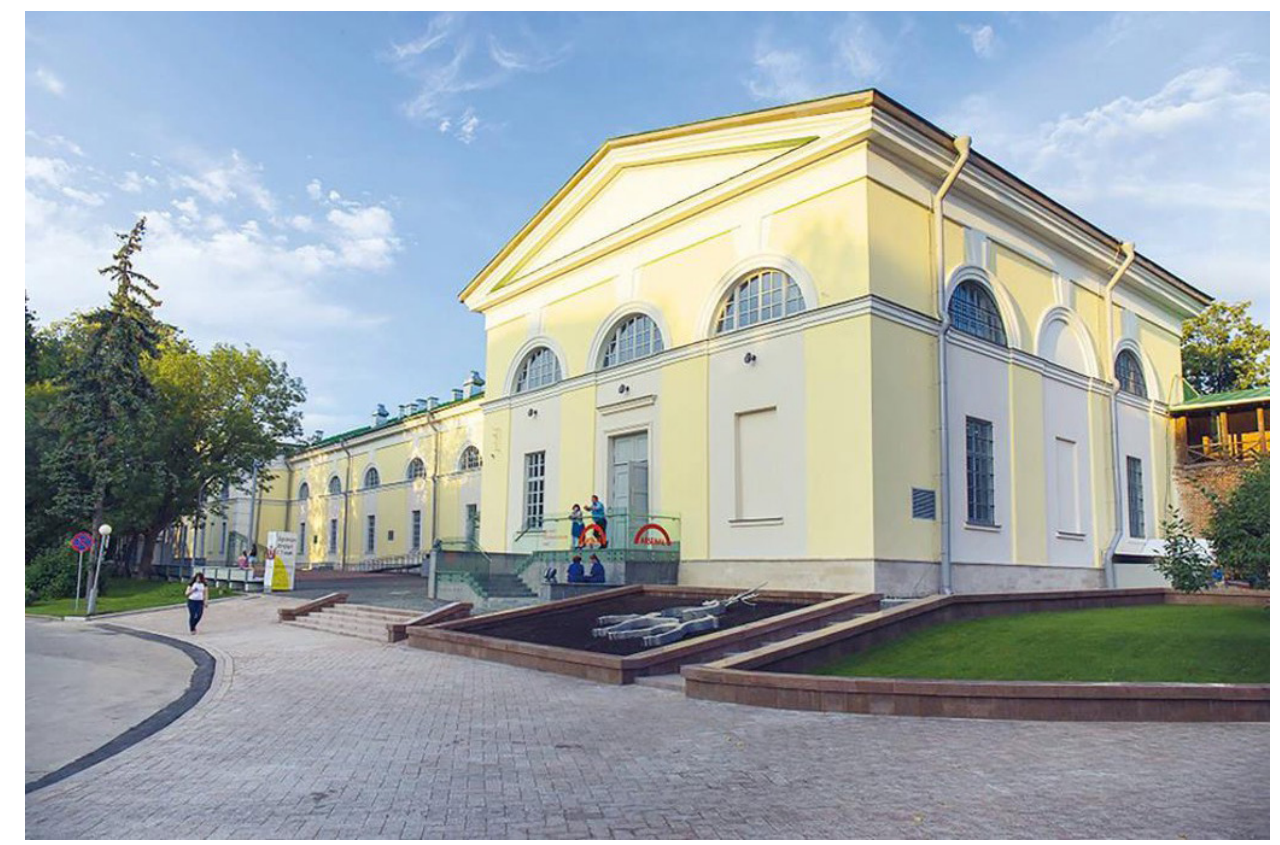

Figure 3. Arsenal building in the Nizhny Novgorod Kremlin. Photo by O. A. Pastukh, 2016

perception of its space, focusing on their emotional response. Certain themes emerged: the quality of light, the feeling of unease while walking on the aged floorboards in the loft, the touch, the age, the dense smell of dust, and the sensation of time. The installation's centerpiece is four steel boxes suspended within the barn, calibrating the scale of the space. Each box contains a series of handblown glass vessels filled with items precious to the barn. In the spirit of Carlo Scarpa's intervention at Museo di Castelvecchio, the final installation remains independent of the existing structure. It is integrated into the barn very delicately and contrasts with it in material and scale (Figure 5).

\subsection{Irving Theater Installation}

In another student project, the Irving Theater Installation, students were asked to propose installations that would amplify or reveal the resonant qualities of the existing space. Paul Reynolds, a

a.

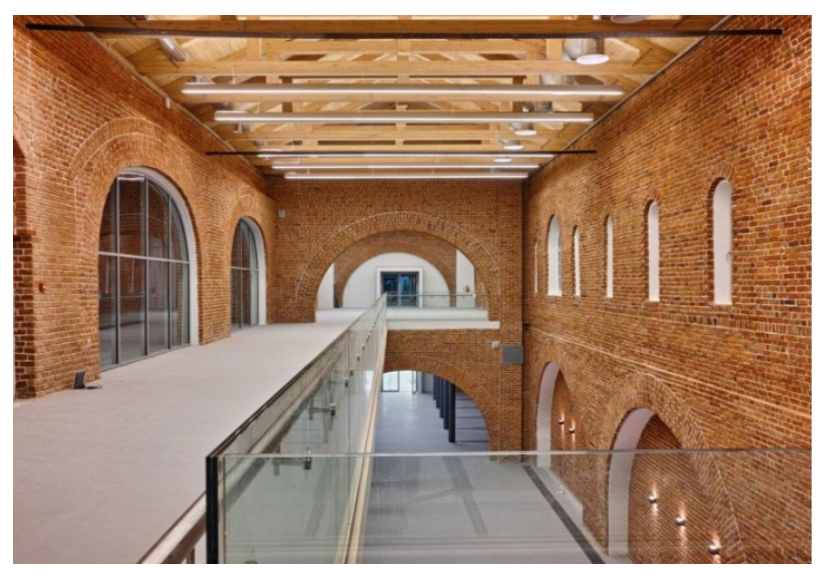

fourth-year architecture student, identified an old opening in an existing wall as a point of interest at the theater, which was in an advanced state of dilapidation and decay. Collaborating with a group of contemporary dancers, Reynolds created an installation that provides a platform for creative movement and amplifies both the potential and the understanding of the existing environment. The Reynolds installation treats the existing structure with the reverence and respect typically reserved for something precious and is attached through a cleverly designed system of compression joints, which clamp to the existing opening when loaded. Leather pads are used as supports where the platform meets the existing structures, and no fastenings are needed to secure it in the existing opening. The platform can be installed and removed without a trace!

Although not dealing strictly with issues related to conservation and restoration, these types of b.

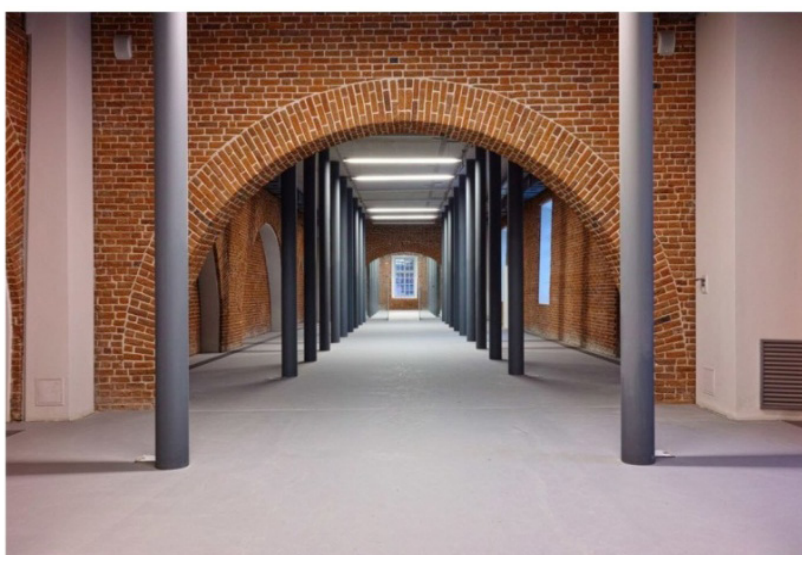

Figure 4. Modern interiors of the Arsenal building in the Nizhny Novgorod Kremlin. Photo by O. A. Pastukh, 2016 
a.

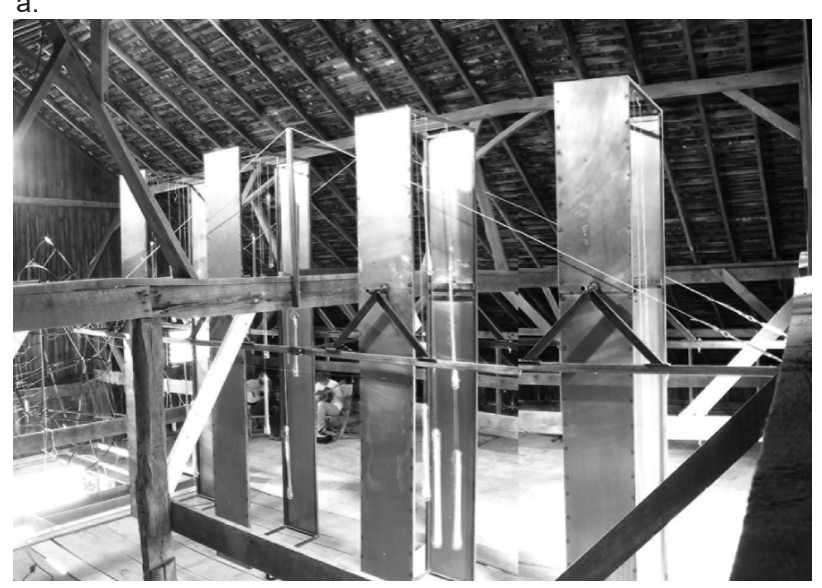

b.

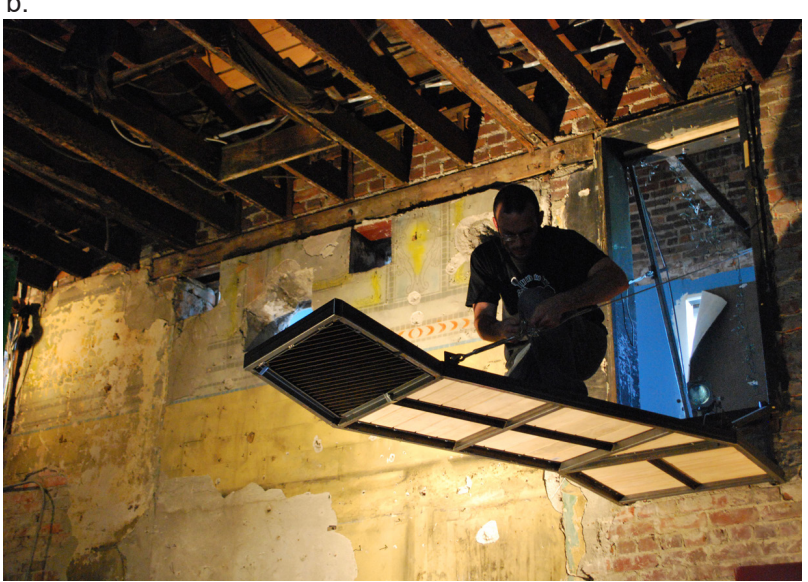

Figure 5. RedBARN Installation, Gray/Williams 2004; Irving Theater Installation, Gray/Reynolds, 2008

projects encourage students to develop a more profound understanding of the inherent potential that lies in the creative engagement with the existing environments, in addition to giving them a conceptual framework for building upon restoration's rich potential throughout their professional careers.

3. Renovation of Historical Sites in Europe: International Experience

3.1. Küppersmühle Renovation in Duisburg, Germany, Herzog and de Meuron

During the Küppersmühle renovation in Duisburg, Germany, Herzog and de Meuron were asked to convert an iconic industrial facility into a museum to house postwar German art. Narrow strips of vertical glazing are crisply incised into the building's facade, overlapping with the existing openings, which have been filled but not erased. The approach reveals a conviction that the intersection between the new and the old will result in something richer and more interesting than what would have emerged if the existing structure had been either demolished, left unchanged, or recreated. We find the same concept in the Italian aesthetic, where the layers of different modifications through time and history are often worn with pride on buildings' facades (Figure 6).

\subsection{Gothic Church in Müncheberg, Germany}

In Müncheberg, Germany, a creative solution was used to breathe life into the ruins of a Gothic church that had been badly damaged in World War II and remained in that state until its restoration in the 1990s. To help raise money for the restoration, the parish partnered with the municipality to share the space as both a spiritual and a civic center, creating a hybrid structure that breathed a new life into the historical building. Architect Klaus Block inserted a new structure, housing a library, a community office, a council chamber, and lavatories, into the shell of the existing cathedral, creating a rich interplay of the new and the old (Figure 7).

\section{Discussion}

Reconstruction of historical objects using modern construction materials is a topic that draws the attention of construction industry professionals and
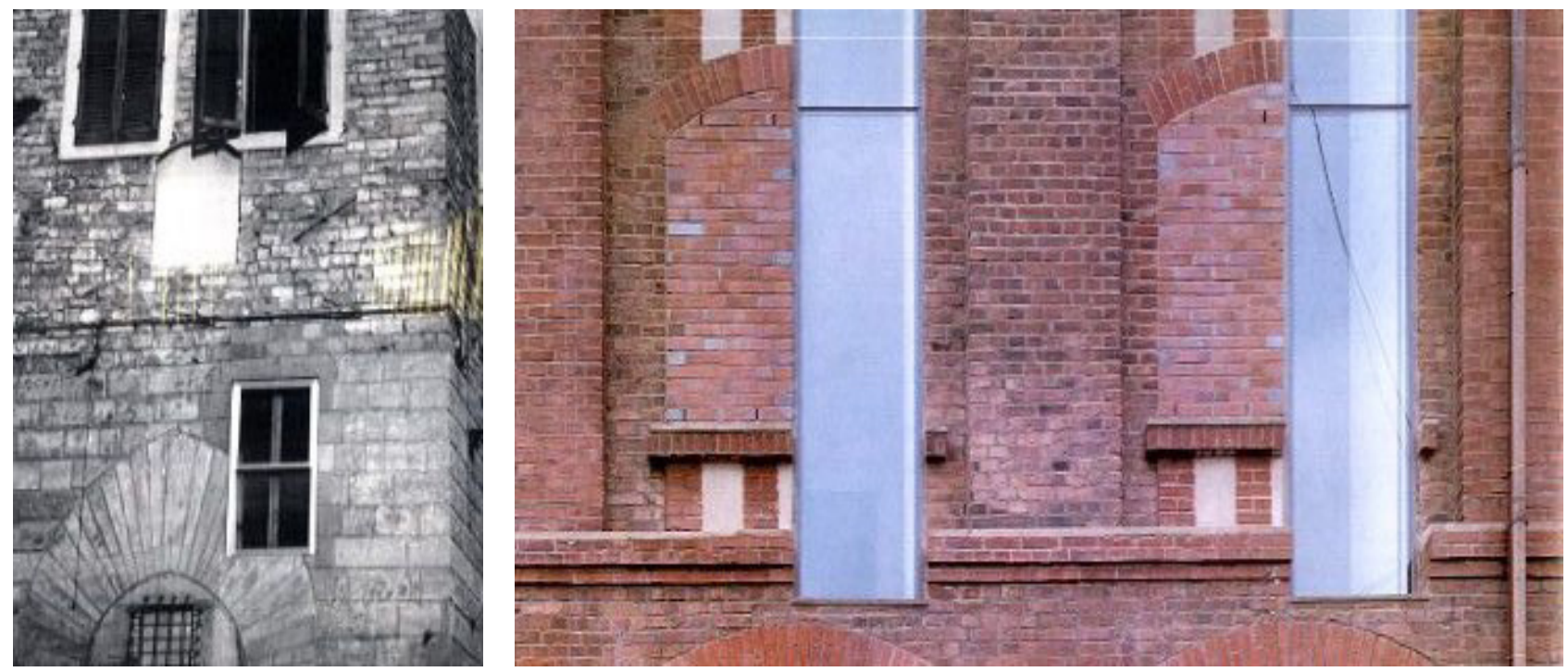

Figure 6. Building facade, Firenze, Italy; window detail, Küppersmühle, Herzog \& de Meuron, 1999 
the general public. Residents, officials, architects, representatives of the business community and investors, as well as large construction companies must reach a consensus and have their interests represented as they discuss how to preserve historical monuments. This problem should be discussed at the international, national, city, municipal, and local level, and the discussion can be extended to the service life of ordinary residential buildings, which are often outdated and inefficient.

Saving energy and improving energy efficiency in construction and utilities is a global priority. It is known that buildings account for $40 \%$ of energy consumption in many countries around the world (Caird et al., 2012). Old housing stock, as a rule, suffers from significant heat loss and overheats through the enclosing structures.

Therefore, the most important measures in the construction sector include reducing energy consumption, using renewable energy sources in order to lower energy dependence on oil-producing countries, and reducing greenhouse gas emissions. The building's microclimate can be negatively affected by the refusal to use environmentally friendly natural materials and the use of outdated air purification technologies for climate control.

In order to upgrade the housing stock, save energy, and use the natural resources more a.

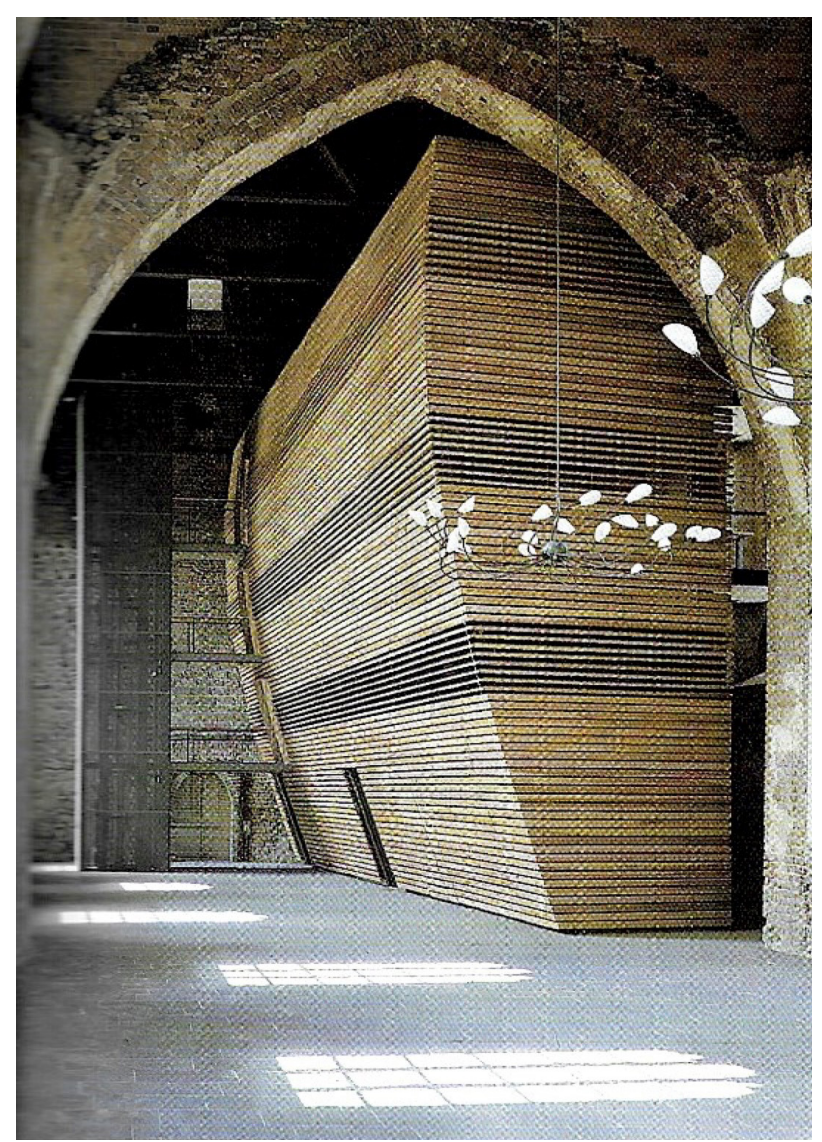

rationally, authorities from the capitals of all eight World Green Building Council member nations (the USA, Australia, Spain, the UK, Japan, the UAE, Russia, and Canada) launched a special urban program. This program was designed for the long term. Its objective was not only to upgrade the old housing stock and preserve historical monuments but also to improve the living conditions and promote a greater sense of community among the local residents (Pastukh et al., 2019).

Green standards are aimed at regulating a sustainable approach to construction, assessing the buildings' degree of compliance with the basic requirements, and speeding up the transition from the traditional design and construction of buildings and structures to sustainable practices. Basic principles of sustainable construction:

1. creating safe conditions that are favorable to human health;

2. limiting the negative impact on the environment;

3. considering the interests of future generations.

It is interesting to hear what well-known practitioners in the field of preserving the historical urban environment and individual monuments think about introducing modern construction materials and organizing the reconstruction process, b.

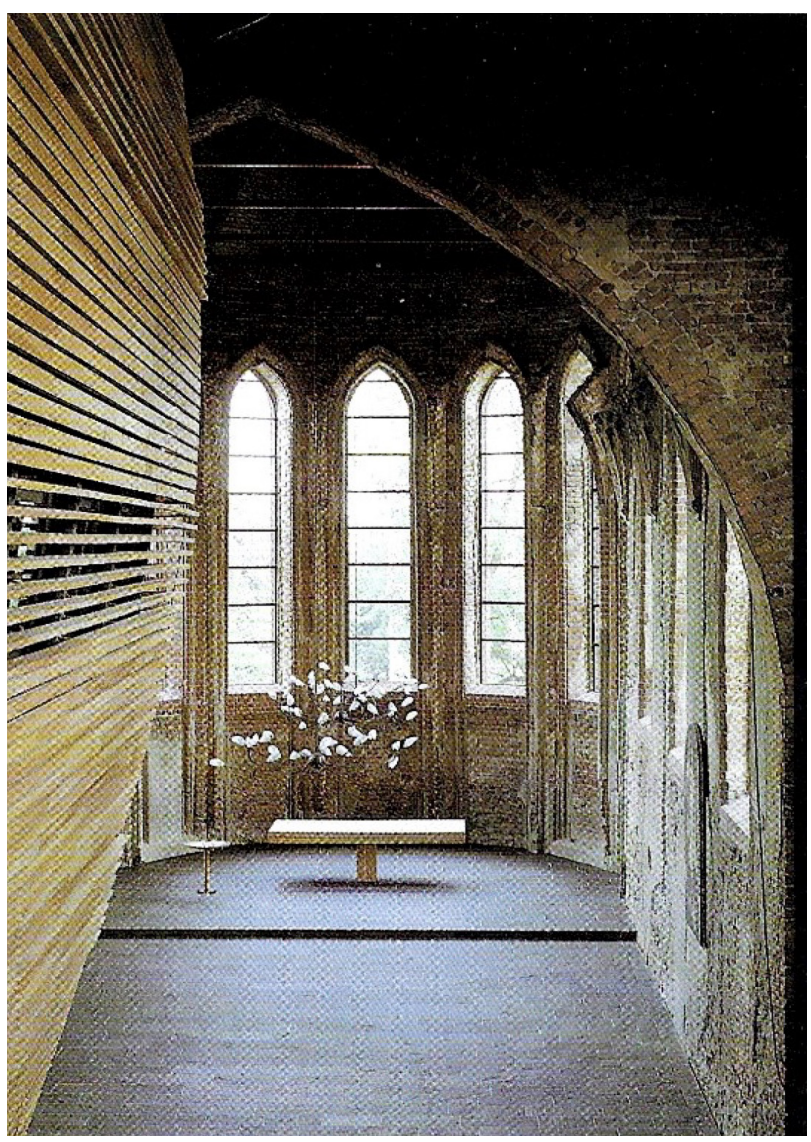


depending on the specifics of their work experience.

Over the recent years, the state of the environment in the world has not changed much for the better. The ongoing natural disasters force humanity to think about the need to reduce $\mathrm{CO}^{2}$ emissions and to create technical solutions that will help use natural materials with minimal waste during the production process. In construction, these include sustainably harvested timber and timber-based materials. Timber is a constantly renewable resource; it is also easy to process and does not leave any inorganic substances after use (Pastukh et al., 2020).

Polymer materials are of interest as well, due to their technical, physical, and mechanical properties. The wide range of properties of these materials, altered through various manufacturing methods, opens up a lot of opportunities for scientific and technical solutions in the future.

Solutions for the production of metal geodesic domes and reinforced concrete structures are widely used in modern practice. However, the authors of this paper believe that the combination of timber and polymer materials in geodesic dome construction is the most advantageous option from every point of view: that of engineering, funding, economics, energy, and even environmental issues.

\section{Conclusions}

By using construction materials and technical solutions taken from the official catalogs of construction companies, one can design buildings that meet the requirements of international standards such as LEED, BREEAM in Europe, Energy Star in the USA, and the Russian standards of green construction (GREEN ZOOM). A set of measures for the renovation of specific historical monuments sets a direction for the improvement and development of the entire territory and is aimed at creating a comfortable urban environment and improving the economic viability and long-term development of both individual districts and cities as a whole.

Shielding cultural heritage sites with geodesic domes, made out of timber and composite materials, will create favorable conditions for the preservation, conservation and restoration activities in all weather conditions.

The technical solution for creating a geodesic dome in the form of a protective shield over cultural heritage sites will slow down the process of their deterioration, improve restoration quality, reduce the risks of performing low-quality work, and allow for the restoration of objects of any complexity in any weather conditions.

As for the execution of specific restoration and reconstruction projects, the importance of international cooperation in the field of restoring and protecting cultural heritage is quite clear. The growing volume of conservation and restoration work is contributing to the urgent need to develop scientific approaches and methodologies that will help solve practical problems. Therefore, engineering practices relevant to the conservation of architectural monuments require close attention and cooperation of various experts, primarily architects, restorers, engineers, and archaeologists.

Preservation of historical and cultural monuments is the main task of engineering conservation and restoration. Each monument has inherent individual features, which add special value. Production methods must be constantly improved, thus reducing labor intensity.

Much has been done in Russia to preserve the cultural heritage of the past, including architectural, cultural, and historical monuments. The capabilities of modern construction equipment and new construction materials are almost limitless. Currently, one can straighten, restore, lift, move, and save any monument, even in a state of disrepair, without changing its appearance. The use of modern construction materials in the reconstruction of historical monuments will not only extend the monuments' service life but also contribute to preserving the environment on our planet. 


\section{References}

Caird, S., Roy, R. and Potter, S. (2012). Domestic heat pumps in the UK: user behaviour, satisfaction and performance. Energy Efficiency, 5 (3), pp. 283-301.

Farahat, B. I. and Osman, K. A. (2018). Toward a new vision to design a museum in historical places. HBRC Journal, 14 (1), pp. 66-78. DOI: 10.1016/j.hbrcj.2016.01.004.

Federal Law No. 73-FZ of June 25, 2002 (edited on December 30, 2015) «On objects of cultural heritage (monuments of history and culture) of the peoples of the Russian Federation» (edited and amended, effective from January 01, 2016), Chapter 7. [online] Available at: https://base.garant.ru/12123142/ [Date accessed October 4, 2020].

Handel, E. M. (2013). Engineering works in the restoration of architectural monuments. Moscow: Architecture-S, 208 p. Irwin, R. (1985). Being and circumstance: notes toward a conditional art. San Francisco: Lapis Press, 157 p.

Jurow, A. (1978). Evocative decay and the maintenance of memory. MSc Thesis in Architecture. Berkeley: University of California, Berkeley.

Kharlamov, M. V. (2011). Methods of creating the lighting image in architecture. Bulletin of Civil Engineers, 3, pp. $28-33$. Lowenthal, D. (1985). The past is a foreign country. Cambridge: Cambridge University Press, $489 \mathrm{p}$.

Lysova, A. I. and Sharlygina, K. A. (1979). Reconstruction of buildings. Leningrad: Stroyizdat, 304 p.

Pastukh, O. A. (2016). The reconstruction plan of the Oka River (1935). Its role and significance for the historical Russian cities of the Moscow region during the period of industrialization. In: Lapshin, A. A. (ed.). 18 $8^{\text {th }}$ International Scientific and Industrial Forum «Great Rivers' 2016». Abstracts of the "Great Rivers' 2016» Scientific Congress Reports. In 3 volumes. Vol. 3. Nizhny Novgorod: Nizhny Novgorod State University of Architecture and Civil Engineering, pp. 141-143.

Pastukh, O., Elistratov, V., Golovina, S. and Elistratov, N. (2019). Renovation of the block in Madrid in accordance with criteria of Isover MultiComfort House. E3S Web of Conferences, 91, Topical Problems of Architecture, Civil Engineering and Environmental Economics (TPACEE 2018), article No. 02005. DOI: 10.1051/e3sconf/20199102005.

Pastukh, O. A., Gray, T.C., Golovina S. (2020). Restored layers: reconstruction of historical sites and restoration of architectural heritage: the experience of the United States and Russia (case study of St. Petersburg). Architecture and Engineering, 5 (2), pp. 17-24. DOI: 10.23968/2500-0055-2020-5-2-17-24.

Pastukh, O. and Zhivotov, D. (2020). Construction of geodesic domes made of wood and composite materials during restoration and conservation of cultural heritage objects. E3S Web of Conferences, 164, Topical Problems of Green Architecture, Civil and Environmental Engineering 2019 (TPACEE 2019), article No, 02020. DOI:10.1051/e3sconf/202016402020.

Town-Planning Code of the Russian Federation No. 190-FZ of December 29, 2004 (edited on December 30, 2015) (edited and amended, effective from January 10, 2016), Chapter 14 of Federal Law No. N 337-FZ of November $28,2011$. [online] Available at: http://publication.pravo.gov.ru/Document/View/0001201808040004?index=11\&rangeSize=1 [Date accessed October 6, 2020].

Tuan, Y.-F. (1974). Topophilia: a study of environmental perceptions, attitudes and values. Englewood Cliffs: Prentice Hall, $260 \mathrm{p}$. 


\title{
РЕКОНСТРУКЦИЯ И ВОССТАНОВЛЕНИЕ ИСТОРИЧЕСКИХ ПАМЯТНИКОВ: МЕЖДУНАРОДНЫЙ ОПЫТ
}

\author{
Ольга Александровна Пастух ${ }^{1 *}$, Тимоти Грей ${ }^{2}$, Светлана Геннадьевна Головина ${ }^{1}$ \\ ${ }^{1}$ Санкт-Петербургский государственный архитектурно-строительный университет \\ 2-ая Красноармейская ул., 4, Санкт-Петербург, Россия \\ 2 Государственный университет Балл \\ Манси, Индиана, США \\ *E-mail: gvolia@yandex.ru
}

\begin{abstract}
Аннотация
Помимо признания и учета важности и необходимости технического обслуживания и ремонта исторических сооружений, в настоящем документе основное внимание будет уделено присущему им проектному потенциалу на пересечении нового и старого. Цель исследования: Подход к реставрации таких памятников, как библиотека в Выборге, здание Арсенала Нижегородского кремля, но также будет сделан акцент на реставрации обычных. В дополнение к памятникам, в этой статье будут рассмотрены примеры, которые не пытаются вернуть здания к какой-то идеализированной версии из прошлого, а скорее используют процесс реставрации, чтобы отпраздновать качества возраста, как они существуют в настоящем, чтобы признать построенную среду живой, развивающейся и постоянно меняющейся. Были использованы следующие методы: Анализ типовых решений для различных целей и объектов в виде структурно-технологических приемов охраны объектов культурного наследия при проведении реставрационных и адаптационных работ. Для того чтобы сохранить использование современных материалов в реставрации и технологий строительства защитных сооружений, он будет заботиться об окружающей среде с учетом стандартов LEED, BREEAM, программы Energy Star в CШA и GREEN ZOOM. Результаты: Авторы предложили избранные примеры из современной практики в Европе, США и России, чтобы проиллюстрировать эти подходы к реставрации, включая две студенческие архитектурные инсталляции, которые исследуют творческое пересечение нового и старого. Обсуждение хода реализации конкретных проектов реставрации и реконструкции показало важность международного сотрудничества в разработке образовательных стратегий и практик в области реставрации и охраны культурного наследия. Растущий объем консервационно-реставрационных работ оказывает давление на развитие научных подходов и методик решения практических задач. В то же время реставратор должен признать, что преемственность С прошлым может существовать при реконструкции более приземленных и утилитарных структур, которые могут извлечь выгоду из менее ограничительных подходов к пересечению старого и нового.
\end{abstract}

\section{Ключевые слова}

Архитектурное наследие, реставрация, адаптация, инновации, исторические строительные конструкции, европейский, российский и американский опыт, архитектурные инсталляции. 